\section{Apes or angels?}

SIR - The description of the punctuated equilibrium model as Marxist ${ }^{1}$, although correct, obscures its real importance in the thinking of east coast radicals: the theory is at root anti-racist. As the debate between Rose $^{2}$ and Dawkins ${ }^{3}$ made clear, the radical scientific opposition to racism requires a denial that there is any genetic variation of any significance from place to place within the human species. As there is a considerable amount of geographical variation in anthropometric characters and in the frequencies of blood groups and other biochemical traits, anyone who wishes to espouse both the neo-Darwinian synthesis and this form of scientific anti-racism must adopt the argument either that the genes affecting behaviour just happen not to be subject to any effective geographical variation in their distribution ${ }^{4}$, which is uncomfortably close to special pleading, or that behaviour is not under genetic control. As this second proposition is known to be untrue for other animals, there is an urgent need for a general theory that will rescue scientific anti-racism from sophistry.

The punctuated equilibrium theory $y^{5,6}$ holds that all species make qualitative "leaps" at the time they originate. This can be applied to humans as meaning that the particular and special "leap" made by our species was largely in freeing the functioning of the brain from genetic influences: no matter how genedistributions may vary geographically, or hormones between the sexes, the psyche is entirely buffered against these and is influenced only by the environment ${ }^{7}$. Further, human races are nowhere near to speciation and hence, not having "leapt", are fundamentally "the same". The punctuated equilibrium theory is thus the modern radical version of Disraeli's famous question and answer "Is man an ape or an angel?". Gould is on the side of the (evolutionary) angels.

However, a belief in the absolute moral value of one's own theological (or scientific) position carries its own danger of personal damnation; this is the lesson of all witchhunts. Although Gould ${ }^{8}$ would like us to believe that he is the potential victim this, in view of recent history, is a piece of chutzpah. Within the academic community it is those scientists whose theories could be convenientiy labelled "racist" or "right-wing" who have been subjected to unof ficial but nonetheless unpleasant persecution (the assault on Eysenck).

Most scientists do not, as Gould ${ }^{8}$ implies, resent the implication that their theories may be founded in their socio-political world-view: they simply regard this obvious fact as irrelevant. The argument that a theory is incorrect merely because the proponent has ulterior motives for holding it has been known as a species of false logic since the ancient Greeks. However, as radical scientists just do not accept the fact-value separation which Dawkins $^{3}$ and other liberals use to defend their position, but rather adopt the Marxist view that moral statements are founded in objective reality (the only true science is that which serves the good of the people) ${ }^{9}$, they interpret the moral statement that racism is wrong as implying the scientific statement that sociobiology is wrong. And as the Soviet ambassadors in Islamic countries have been trying to explain recently, it is important to distinguish a progressive force which swims with the moral tide of history from a reactionary imperialist force which swims against it. Perhaps the same distinction applies to witch-hunts.

\section{Department of Genetics, \\ University of Leeds, UK}

1. Halstead, L.B. Nature 288, 208 (1980).

2. Rose, S. Nature 289, 335 (1981); 290, 431-432 (1981).

3. Dawkins, R. Nature 289, 528 (1981)

4. Cavalli-Sforza, L.L. \& Bodmer, W.F. The Genetics of Human Populations (W.H. Freeman, San Francisco. 1971).

5. Stanley, S.M. Macroevolution, Pattern and Process (W.H. Freeman, San Francisco, 1979).

6. Lewin, R. Science 210,883-887 (1980)

7. Futuyma, D.J. Evolutionary Biology (Sunderland, Massachusetts, 1979).

8. Gould, S.J. Nature 289, 742 (1981)

9. Brecht, B. Leben des Galilei (Frankfurt, 1955).

\section{It wasn't me}

SIR - You recently published a letter on genetic determinism from someone in Massachusetts with a name remarkably similar to mine. My acquaintances all seem to think that I wrote that letter, so I wish to state publicly that this is not the case. His first name is spelled "Isadore".

University of Chicago,

ISIDORE NABI Illinois, USA

\section{Unsöld on Einstein}

SIR - I feel that the article "German physics in row about Einstein"' (Nature 16 April, p.535), dealing with a lecture and a publication of mine, needs some correction. It states that I began my "attack on Einstein" at a symposium held last May. In fact, this refers to a lecture, "Evolution of cosmic, biological and metal structures", which I gave on 25 April 1980 at a physics colloquium at the University of Marburg. With regard to the evolution of mankind, I mentioned the alarming problem of weapons and actions of mass destruction (gas warfare, the atomic bomb, napalm, atomic and neutron rockets, and, of course, Hitler's genocide), for which highly intelligent people were responsible. In the discussion which followed, no one, from an audience of some 200 , said anything about Einstein. However, weeks later, a Marburg professor wrote to many physicists, complaining bitterly about my lecture.

As to my article in Physikalische Blätter dealing primarily with the Einstein celebrations of $1979, \mathrm{I}$, of course, fully acknowledge the great discoveries of Einstein, but I strongly disagree with the many statements which attempt to show him as a great politician or even a kind of saint. And I disagree still more with a prominent speaker who claimed that, compared with Einstein, Planck's political attitude was "childlike".

Being no historian, I took almost all my biographical information from the book Einstein, the Life and Times by Ronald W. Clark, a prominent British historian of science. And the president of the Society for History of Sciences, Professor F. Krafft, stated in a letter of 29 April 1981 that, as far as he could see, my article contained no false statements or quotations.

The publication of my article was solely the responsibility of the five editors, one of whom was Professor Rollnik. Any attempt to shift the editorial responsibility to others would be quite unfair.

As to the reaction of others, I would like to emphasize that I received many letters of support from prominent scientists, while it seems Professor Rollnik received most of those which disagreed with me. Several of them seem to use the term "Nazi" in exactly the same way the Nazis used the term "White Jews", in order to outlaw all theoretical physicists in Germany!

AlBReCht UnsÓLD

Institute of Theoretical Physics, University of Kiel, FRG

SIR - Under the West German press laws I am the editor responsible for the Physikalische Blätter, the journal of the German Physical Society, and would like, in this capacity, to say a few clarifying words on the article "German physics in row about Einstein" (Nature 290, 535; 1981).

I intentionally did not involve Professor Rollnik, the president of the German Physical Society and co-publisher of the journal, in the discussions on the publication of Professor Albrecht Unsöld's manuscript as I do not consider it a good thing for the president of a scientific society to decide on the views, political or otherwise, of the society's members. A society's journal, which reflects only the opinions of the president, would indeed be a questionable enterprise.

I therefore much regret that Herr Rollnik has been rebuked. Why did the critics not write to Professor Unsöld or to the editorial staff?

Unsöld has received many letters agreeing with him and this endorsement largely accords with my reasons for deciding to publish the article: in no way did Unsöld want to enrich the Einstein biographies. He simply wanted to take Einstein (and Haber) as examples to illustrate that the trend towards increasingly more effective means of mass destruction, however well-intentioned they are subjectively, ultimately only enlarges the catastrophe. Unsöld destroyed the idol "Einstein" in order to get at the main theme of his article, the increasingly dangerous disproportion between man's moral capacities and his intellectual faculties. I am probably not the only one to share this concern with him.

Unsöld speaks expressly of the great "tragedy" of nationalism and how this also involved great natural scientists. This was not meant to discredit, but nor was it intended as antisemitism. Surely it was also tragic that nuclear weapons were developed by leading scientists of a people Hitler had horribly plagued. Nevertheless, this is of little help to us in Central Europe if these weapons are to be used in our countries. Not even the 30,000 Jews who still, or once again, live in Germany could hope to be spared.

Physikalische Blătter,

Karl KROMPHARDT 